\title{
Characterization of the ATPase and Transport Activities of Purified CFTR
}

\author{
Christian J. Ketchum, Garnepudi V. Rajendrakumar, and Peter C. Maloney* \\ Department of Physiology, Johns Hopkins Medical School, Baltimore, MD 21205
}

\section{Abstract}

The cystic fibrosis transmembrane conductance regulator (CFTR) functions in vivo as a cAMPactivated chloride channel. A member of the ATP-binding cassette superfamily of membrane transporters, CFTR contains two transmembrane domains (TMDs), two nucleotide-binding domains (NBDs), and a regulatory (R) domain. It is presumed that CFTR couples ATP hydrolysis to channel gating, and as a first step in addressing this issue directly, we have established conditions for purification of biochemical quantities of human CFTR expressed in Sf9 insect cells. Use of an 8azido- $\left[\alpha^{32} \mathrm{P}\right]$-ATP binding and vanadate-trapping assay allowed us to devise conditions to preserve CFTR function during purification of a $\mathrm{C}$-terminal $\mathrm{His}_{10}$-tagged variant after solubilization with lyso-phosphatidylglycerol (1\%) and diheptanolylphosphatidylcholine $(0.3 \%)$ in the presence of excess phospholipid. Study of purified and reconstituted CFTR showed that it binds nucleotide with an efficiency comparable to that of P-glycoprotein, and that it hydrolyzes ATP at rates sufficient to account for presumed in vivo activity ( $\mathrm{V}_{\mathrm{Max}}$ of $58 \pm 5 \mathrm{nmol} / \mathrm{min} / \mathrm{mg}$ protein, $\mathrm{K}_{\mathrm{M} \text { (MgATP) }}$ of 0.15 $\mathrm{mM})$. In further work, we found that neither nucleotide binding nor ATPase activity were altered by phosphorylation (using Protein Kinase A) or dephosphorylation (with Protein Phosphatase 2B); we also observed inhibition ( $\sim 40 \%)$ of ATP hydrolysis by reduced glutathione, but not by DTT. To evaluate CFTR function as an anion channel, we introduced an in vitro macroscopic assay based on the equilibrium exchange of proteoliposome-entrapped radioactive tracers. This revealed a CFTRdependent transport of ${ }^{125}$ I that could be inhibited by known chloride channel blockers; no significant CFTR-dependent transport of $\left[\alpha^{32} \mathrm{P}\right]$-ATP was observed. We conclude that heterologous expression of CFTR in Sf9 cells can support manufacture and purification of fully functional CFTR. This should aid in further biochemical characterization of this important molecule.

The Cystic Fibrosis Transmembrane conductance Regulator (CFTR) is the cAMP-activated chloride channel encoded by the gene defective in patients with the disease [1,2]. As a member of the ATP-Binding Cassette (ABC) superfamily of membrane transporters, CFTR shares a conserved architecture consisting of two homologous halves, each containing a transmembrane domain (TMD) and a nucleotide-binding domain (NBD). In CFTR, unlike other ABC transporters, a third domain, termed the regulatory $(\mathrm{R})$ domain, is located between the two half molecules. Current evidence suggests that the TMDs define the CFTR chloride channel, while the NBDs and the R domain mediate channel gating [3-11]

Although CFTR is glycosylated, there is currently no evidence indicating that the presence of carbohydrate affects CFTR structure or function [12]. Consistent with this presumption, expression of human CFTR in Sf9 insect cells results in appearance of the $140 \mathrm{kD}$ core polypeptide - containing little or no glycosylation - that mediates a newly acquired anion permeability with the electrophysiological signature of CFTR [13]. Moreover, crude membranes from such cells have been used in vanadate-trapping experiments that demonstrate

\footnotetext{
*Email: pmaloney@jhmi.edu
} 
a functional competence for the CFTR NBDs [14,15]. In this study, we focused on purification of human CFTR from this heterologous expression system as a way to provide amounts of CFTR that might support extended biochemical and biophysical work with purified material. We show that following reconstitution into proteoliposomes, purified CFTR retains its ability to undergo vanadate-trapping of bound nucleotide, that it exhibits a rate of net nucleotide hydrolysis sufficient to achieve maximal channel gating $[16,17]$ and that it displays an anion transport function ( ${ }^{125} \mathrm{I}^{-}$equilibrium exchange) that can inhibited by well-known chloride channel blockers.

\section{MATERIALS AND METHODS}

\section{Sf9 membrane preparation}

Recombinant baculovirus specifying CFTR with a C-terminal decahistidine tag $\left(\mathrm{His}_{10}\right)$ was a gift from Dr. Christine Bear (University of Toronto [18]). The recombinant virus specifying Pgp with the same C-terminal His 10 tag was a gift of Dr. Suresh Ambudkar (NIH). Growth of Spodoptera frugiperda (Sf9 ovarian) insect cells was according to the procedures described by Invitrogen (Carlsbad, CA), with reagents from Life Technologies (Gaithersburg, MD). Briefly, insect cells were maintained in Grace's insect media supplemented with $10 \%$ (v/v) fetal bovine serum and antibiotics ( $100 \mathrm{units} / \mathrm{ml}$ penicillin and $100 \mu \mathrm{g} / \mathrm{ml}$ streptomycin) at a density between 0.6 and 2 million cells $/ \mathrm{ml}$ in Bellco (Vineland, NJ) suspension flasks $(0.01 \mathrm{~L}-1 \mathrm{~L}$ ). For protein expression, cells were infected with recombinant baculovirus carrying the CFTR or Pgp genes ( 5 viral particles per cell) and harvested by centrifugation 60 hours later. Harvested cells were washed with PBS ( $\mathrm{pH} 7.5$ ), suspended in a one-tenth volume of buffer containing $50 \mathrm{mM}$ Tris $\mathrm{HCl}$ (pH 7.5), $50 \mathrm{mM}$ mannitol, $2 \mathrm{mM}$ EGTA, $2 \mathrm{mM}$ DTT, $2 \mu \mathrm{g} / \mathrm{ml}$ aprotinin, and $0.5 \mu \mathrm{g} / \mathrm{ml}$ leupeptin, swollen on ice for $30 \mathrm{~min}$, and lysed by dounce homogenization (typically, 100 strokes). Debris was removed by a low speed centrifugation $(3,000 \mathrm{~g} \times 5 \mathrm{~min})$ and the secondary membrane pellet $(100,000 \mathrm{~g} \times 60 \mathrm{~min})$ was washed with an equal volume of $50 \mathrm{mM}$ Tris $\mathrm{HCl}$ $(\mathrm{pH} 7.5), 50 \mathrm{mM} \mathrm{KCl}, 5 \%(\mathrm{v} / \mathrm{v})$ glycerol, $1 \mathrm{mM}$ EDTA, and $0.5 \mathrm{mM}$ DTT containing freshly added protease inhibitors $(1 \mu \mathrm{g} / \mathrm{ml}$ aprotinin, $0.5 \mu \mathrm{g} / \mathrm{ml}$ leupeptin, $1 \mu \mathrm{g} / \mathrm{ml}$ pepstatin, and 10 $\mu \mathrm{g} / \mathrm{ml} \mathrm{pA}-\mathrm{PMSF}$ ). All steps were performed at $4{ }^{\circ} \mathrm{C}$ or on ice. SDS-PAGE and quantitative immunoblotting with either a rabbit polyclonal anti-R-domain antibody (raised against amino acids 724-746 [19]) or a mouse monoclonal anti-His-tag antibody (Qiagen) were used to confirm expression and to determine the percentage of total membrane protein attributable to CFTR of Pgp (near 1\%; data not shown). Membrane protein concentration was determined by the Bradford assay (Bio-Rad).

\section{Purification of CFTR and Pgp}

For CFTR, Sf 9 membranes were solubilized at $10 \mathrm{mg}$ CFTR $/ \mathrm{ml}$ for $20 \mathrm{~min}$ at $4{ }^{\circ} \mathrm{C}$ in a buffer containing $50 \mathrm{mM}$ Tris $\mathrm{HCl}(\mathrm{pH} 7.5), 50 \mathrm{mM} \mathrm{KCl}, 0.2 \mathrm{mM}$ EGTA, $2 \mathrm{mM}$ ouabain, $10 \mathrm{mM}$ sodium azide, $2 \mathrm{mM} \mathrm{MgCl} 2,1 \mathrm{mM} \mathrm{NaATP}, 20 \%$ (v/v) glycerol, $0.2 \%$ (w/v) E. coli phospholipid (Avanti Polar Lipids), 1\% 1-palmitoyl-2-hydroxy-sn-glycero-3-[phospho-rac(1-glycerol)] (LPG; Avanti Polar Lipids), 0.3\% (w/v) 1,2-diheptanoyl-sn-glycero-3phosphocholine (DHPC; Avanti Polar Lipids), $10 \mathrm{mM}$ imidazole, and protease inhibitors (as above). After removing insoluble material by centrifugation, the supernatant was mixed with Ni-NTA resin (Qiagen; $100 \mu \mathrm{l}$ of $50 \%$ slurry per ml soluble crude extract) that had been washed in the solubilization buffer. The suspension was mixed for $3 \mathrm{hrs}$ at $4{ }^{\circ} \mathrm{C}$ and then washed with 50 volumes $(5 \times 500 \mu \mathrm{l})$ of a buffer containing $50 \mathrm{mM}$ Tris $\mathrm{HCl}(\mathrm{pH} 7.5), 50 \mathrm{mM} \mathrm{KCl}, 2 \mathrm{mM}$ $\mathrm{MgCl}_{2}, 1 \mathrm{mM}$ NaATP, $20 \%$ (v/v) glycerol, $0.1 \%$ (w/v) E. coli phospholipid, $0.1 \%$ LPG, $0.3 \%$ DHPC, and $50 \mathrm{mM}$ imidazole. Purified protein was eluted with 2 volumes of the same buffer lacking LPG, but containing $150 \mathrm{mM}$ imidazole. An amido black 10B assay [20] was employed to determine protein concentration; purity was confirmed by silver-staining (Bio-Rad) and 
immunoblotting of duplicate gels. Pgp was purified in the same fashion except that dodecylmaltoside replaced LPG.

\section{Reconstitution}

Purified protein was reconstituted by detergent dilution [21]. Liposomes were prepared at room temperature with a bath sonicator, using $25 \mathrm{mg}$ hydrated $E$. coli phospholipid suspended in 0.5 $\mathrm{ml}$ of $50 \mathrm{mM}$ Tris $\mathrm{HCl}$ ( $\mathrm{pH} 7.5$ ), $50 \mathrm{mM} \mathrm{KCl}$. After a brief spin to clarify the suspension, the sonicated liposomes were transferred to an Eppendorf tube and octyl- $\beta$-D-glucopyranoside (CalBiochem) was added to $3.75 \%(\mathrm{w} / \mathrm{v})$; one volume of the solubilized liposome mixture was then added to two volumes of solubilized protein. After a 20-min incubation at room temperature, proteoliposomes were formed by rapidly diluting the mixture about 150 -fold into $50 \mathrm{mM}$ Tris $\mathrm{HCl}$ ( $\mathrm{pH} 7.5), 50 \mathrm{mM} \mathrm{KCl}$ (at room temperature), after which they were collected by centrifugation $(180,000 \mathrm{~g} \times 60 \mathrm{~min})$. This method is presumed to allow the random insertion of protein, generating proteoliposomes with an equal distribution of inside-out and right-sideout orientations [21-24]. Protein recovery was measured by an Amido Black 10B assay [20] and confirmed by quantitative immunoblot analysis.

\section{Az-ATP binding and Vi-trapping}

Membranes or proteoliposomes were suspended in a buffer containing $50 \mathrm{mM}$ Tris $\mathrm{HCl}(\mathrm{pH}$ 7.5), $50 \mathrm{mM} \mathrm{KCl}, 2 \mathrm{mM} \mathrm{MgCl}_{2}, 0.1 \mathrm{mM}$ EGTA, $2 \mathrm{mM}$ ouabain, and $5 \mathrm{mM}$ sodium azide supplemented with 5-50 $\mu \mathrm{M}$ 8-azido- $\left[\alpha^{32} \mathrm{P}\right]$-adenosine-5'-triphosphate (Az-ATP; Affinity Labeling Technologies), in the absence or presence of $0.5 \mathrm{mM}$ sodium orthovanadate (Vi; Sigma). The Vi was prepared as detailed by Goodno [25], and the Vi concentration of stock solutions determined by molar absorbance $\left(\lambda_{268 \mathrm{~nm}}=3600 \mathrm{M}^{-1}\right)$. After incubation for $4 \mathrm{~min}$ at $37^{\circ} \mathrm{C}$ to allow for nucleotide binding and trapping, $10 \mathrm{mM} \mathrm{MgATP}(\mathrm{pH} 7.5)$ was added to reduce non-specific binding. Samples were then irradiated with UV light $(365 \mathrm{~nm})$ for $10 \mathrm{~min}$ at a fixed distance of $5 \mathrm{~cm}$, after which labeled proteins were separated by SDS-PAGE, visualized by autoradiography (Kodak X-OMAT Film and/or a Fuji Phophorimager) and quantified (arbitrary units) using a Fuji Phosphoimager and Fuji Image Gauge V3.3 imaging software.

\section{ATPase assay}

ATP hydrolysis by CFTR was evaluated using proteoliposomes placed at $37^{\circ} \mathrm{C}$ in a buffer containing $50 \mathrm{mM}$ Tris $\mathrm{HCl}$ (pH 7.5), $50 \mathrm{mM} \mathrm{KCl}, 2 \mathrm{mM}$ ATP, $2 \mathrm{mM} \mathrm{MgCl}_{2}, 0.1 \mathrm{mM}$ EGTA, $2 \mathrm{mM}$ ouabain, and $5 \mathrm{mM}$ sodium azide, supplemented with 5-10 $\mu \mathrm{Ci}\left[\alpha^{32} \mathrm{P}\right] \mathrm{ATP}$. At defined time-points, aliquots were removed, quenched by addition of $2.5 \%(\mathrm{w} / \mathrm{v})$ SDS, and spotted on a polyethyleneimine-cellulose plate (J. T. Baker). Hydrolyzed [ $\left.\alpha^{32} \mathrm{P}\right]$ ADP was separated from $\left[\alpha^{32} \mathrm{P}\right]$ ATP by thin-layer chromatography in $1 \mathrm{M}$ formic acid, $0.5 \mathrm{M} \mathrm{LiCl}$. Radiolabeled nucleotides were visualized by a Fugi Phosphoimager and quantified (as above). To account for the spontaneous Mg-catalyzed hydrolysis of ATP, all values were corrected by comparison with parallel control samples containing liposomes (no protein). All assays were performed under conditions where ATP hydrolysis was linear with both time and protein content.

\section{Transport assay}

CFTR-dependent anion transport activity was measured by the equilibrium exchange of proteoliposome-entrapped radioactive tracers [26,27]. Proteoliposomes were formed by detergent dilution (as above) in a buffer containing $50 \mathrm{mM}$ Tris $\mathrm{HCl}$ (pH 6.8), $50 \mathrm{mM}$ KI, 50 $\mathrm{mM}$ potassium glutamate $(\mathrm{pH} 6.8)$ and $1 \mathrm{mg} / \mathrm{ml}$ DTT in the presence of $100 \mu \mathrm{Ci}^{125} \mathrm{I}$ and 100 $\mu \mathrm{Ci}{ }^{3} \mathrm{H}$-glutamate. Proteoliposomes were collected by centrifugation, after which the surface of the pellet was rinsed with loading buffer (above) to which tracer had not been added. ${ }^{125}$ I release was then initiated by resuspending the pellet in $1 \mathrm{ml}$ of the same buffer. After a $1 \mathrm{~h}$ 
incubation at room temperature, aliquots were collected by vacuum filtration onto presoaked Millipore GS filters $(0.22-\mu \mathrm{m}$ pore size $)$ and washed with tracer-free buffer $(3 \times 1 \mathrm{ml})$. Residual isotope remaining on the filter was used as the index of CFTR-mediated anion flux.

\section{RESULTS}

\section{Overexpression of CFTR in Sf9 insect cells}

It was shown earlier that coincident with expression of human CFTR in Sf9 insect cells there is appearance of a new anion permeability with features appropriate to a CFTR-mediated anion channel [13]. And by use of a vanadate (Vi)-trapping assay, CFTR-specific ATP binding and hydrolysis has also been observed in the crude membranes of such cells [14,15]. Indeed, because of its high sensitivity, we used this latter method to evaluate conditions suited to purification of human CFTR expressed in these cells. Vi is a structural analog of inorganic phosphate $[28,29]$ and arrests the hydrolytic cycle of an ATPase at an intermediate stage, after nucleotide hydrolysis and release of phosphate, but before release of $\operatorname{ADP}(e . g$.,

$\mathrm{CFTR} \cdot \mathrm{MgADP} \bullet \mathrm{Vi})$. In the presence of $\mathrm{Vi}$, therefore, the entire population can be forced to accumulate in a single "trapped" state whose lifetime is considerably extended relative to the normal intermediate. If done in conjunction with a photolabile ATP analog, such as 8-azido-

$\left[\alpha^{32} \mathrm{P}\right]$-ATP (Az-ATP), irradiation with UV light can cross-link (at low efficiency) the trapped nucleotide to the peptide backbone, generating a stable radioactive species whose presence reports the parent population. Figure 1 shows that crude Sf9 membranes harboring CFTR, but not those expressing $\beta$-galactosidase ( $\beta \mathrm{gal})$, display $\mathrm{Vi}$-stimulated incorporation of radionucleotide into a protein migrating at a position corresponding to that of CFTR. This finding confirms that human CFTR can bind and hydrolyze ATP in this heterologous cell culture system.

\section{Purification of CFTR from Sf9 membranes}

Purification of membrane proteins such as CFTR requires their dissociation from other bound proteins and membrane lipids by solubilization with a compatible detergent. To determine which detergent(s) might be best for extracting functional CFTR from Sf9 membranes, we monitored solubilization using the Az-ATP binding and Vi-trap described above (Fig. 1). In such experiments, $\mathrm{Sf} 9$ membranes were subjected to detergent solubilization either before or after Az-ATP binding and trapping; in each case, the UV cross-linking of Az-ATP to the polypeptide backbone was performed last, after detergent solubilization. We found that when exposure to detergent occurred before Az-ATP binding and the Vi-trap, no CFTR-specific incorporation of the labeled nucleotide could be observed, despite significant extraction of protein (Fig. 2b). This suggests that detergent-solubilized material is unable to bind and/or hydrolyze nucleotide. By contrast, when detergent solubilization took place after Az-ATP binding and the Vi trap (but before cross-linking), the nucleotide incorporation observed in membranes was preserved to varying degrees according to the detergent(s) used. In these cases, we found that a detergent combination of LPG [30] and DHPC faired best, retaining > 85\% of the CFTR-specific signal seen in crude membranes (Fig. 2). By contrast, detergents used previously as CFTR-solubilizing agents (e.g., Triton X-100, SDS and NaPFO [31]) supported little or no retention of labeling, indicating that these agents gave at least a partial denaturation of the CFTR NBDs.

We interpreted these data (Fig. 2) as indicating that nucleotide (e.g., MgATP) must be included during solubilization to ensure recovery of functional CFTR. Accordingly, we used the detergent combination noted above (LPG/DHPC), along with $1 \mathrm{mM} \mathrm{ATP}$, as the starting point for purification of CFTR by Ni-agarose affinity chromatography [32] (see Methods). The final preparation was of high purity (> 95\%) as judged by silver staining (Fig. 3), with a net yield of $1 \mu \mathrm{g} \mathrm{CFTR/ml} \mathrm{culture}\left(1.6 \times 10^{6}\right.$ cells $)$, corresponding to a final recovery of about $10-15 \%$ 
of solubilized CFTR. In part this low yield was due to poor binding of solubilized CFTR to the Ni-agarose column (see Fig. 3). Preliminary work now indicates that yield may be increased to $50-70 \%$ of the solubilized material by either reapplication of unbound material to Ni-agarose or by use of increased amounts ( 2 to 3 -fold) of resin (Ye \& Maloney, unpublished). These steps, however, lead to a somewhat reduced final purity (80-90\%), and the experiments reported here used the highly purified material obtained by a single batch exposure to the resin (as in Fig. 3). A second factor contributing to reduced yield was inefficient disruption of cells from large culture volumes (> $200 \mathrm{ml}$ ). This may be related to use of homogenization to disrupt cells, since solubilization was markedly increased when membranes were dispersed using high pressure lysis (14,000 p.s.i) (Ye \& Maloney, unpublished).

\section{Nucleotide processing by purified and reconstituted CFTR}

Purified membrane proteins are best studied after the detergent(s) used for solubilization has been replaced by phospholipid. In our work, this was accomplished by reconstitution of CFTR using a detergent dilution method $[21,33]$ ) that yields proteoliposomes suited to characterization of nucleotide processing by ABC transporters (see [34]). Our initial trials used the Vi-trap of ${ }^{32} \mathrm{P}$-labeled Az-ATP, as in earlier work. These experiments documented the expected dependence on divalent cation $\left(\mathrm{Mg}^{2+}\right)$, as well as the stimulation afforded by a $\mathrm{Vi}$ trap (Fig. 4ab). Of interest is the significant incorporation of labeled nucleotide in the absence of a Vi trap (Fig. 4ab). This behavior, noted by others in studies of crude membranes [14,15], has not been reported for other $\mathrm{ABC}$ transporters $[14,15,33]$ and may be a distinctive feature of CFTR.

We also evaluated recovery of functional CFTR in a quantitative manner by comparing nucleotide trapping of CFTR in parallel with that of its well-characterized relative, Pgp, which had been expressed in Sf9 cells and purified and reconstituted using conditions optimized for its own recovery [33,35-37,38] (Table I,Fig. 4c-e). In both instances, we observed Vistimulated nucoleotide binding, although signals associated with CFTR were markedly reduced relative to that found for Pgp (Fig. $4 c d$ ). Because these two proteins each carried the same Cterminal $\mathrm{His}_{10} \mathrm{tag}$, we used an anti-polyhistidine antibody in a quantitative immunoblot analysis (Fig. 4e) that indicated this differential reaction was entirely attributable to a reduced content of CFTR in target proteoliposomes. Indeed, when the data were expressed on a molar basis (with correction for protein content and molecular weight), we concluded that CFTR and Pgp bind nucleotide (Az-ATP) with approximately equal efficiency (109\% vs. 100\%, respectively). Since the biochemical characteristics of Pgp purified from Sf9 cells (e.g., $\mathrm{V}_{\max }, \mathrm{K}_{\mathrm{M}}$, and substrate stimulation) match values cited in the literature for the fully functioning molecule [33,35-38] (Table I), we conclude that nucleotide processing by purified CFTR exhibits characteristics similar to that of Pgp.

In mammalian systems, R domain phosphorylation must occur before CFTR chloride channel function is observed. However, in Sf9 cells, the CFTR-mediated anion conductance appears without addition of exogenous stimuli that might activate intracellular protein kinases and promote $\mathrm{R}$ domain phosphorylation [13]. This suggests that in these cells, the $\mathrm{R}$ domain of CFTR either constitutively phosphorylated, or that, for unknown reasons, $\mathrm{R}$ domain regulation does not operate in these cells. Since the phosphorylation status of purified CFTR is unknown, we monitored the effects of both dephosphorylation and phosphorylation to determine whether in vitro treatment might affect nucleotide binding. Treatment with Protein Phosphatase 2B (PP2B), a relevant phosphatase in vivo [39], had no apparent effect on the SDS-PAGE mobility of CFTR, while exposure to cAMP-dependent Protein Kinase (PKA) caused a clear retardation in CFTR mobility (Fig. 4fg) (see Table II and [16] for methods), coincident with phosphorylation as documented by labeling by $\left[\gamma^{32} \mathrm{P}\right]$ ATP (data not shown). Moreover, the mobility shift induced by PKA was readily reversed by subsequent exposure to PP2B (Fig. 
$4 f g$ ). But despite that CFTR could be phosphorylated and dephosphorylated in vitro, CFTRdependent nucleotide binding remained unaffected (Fig. 4f). This is consistent with the in vivo observations made with Sf9 cells, raising the possibility that nucleotide binding is independent of $\mathrm{R}$ domain phosphorylation.

\section{ATP hydrolysis by purified and reconstituted CFTR}

The Vi trap used to monitor nucleotide binding (Fig. 4) limits the analysis to a partial turnover of a binding domain. To study net ATP hydrolysis, we measured liberation of $\left[\alpha^{32} \mathrm{P}\right] \mathrm{ADP}$ from $\left[\alpha^{32}\right.$ P]ATP [16] (Fig. 5). In our initial work, we found that CFTR hydrolyzes ATP at a maximal rate of $58 \pm 5 \mathrm{nmol} / \mathrm{mg} / \mathrm{min}$, with a $\mathrm{K}_{\mathrm{M}}$ for MgATP of $0.15 \mathrm{mM}$ (Fig. $5 a$, Table II). These values are consistent with previous reports for CFTR [16,40] and also for several other ABC transport proteins, including Ste6p, ABCR, MRP1 and MRP2 [33,41-43]. Moreover, if one assumes that ATP hydrolysis is linked to channel gating, these values are sufficient to achieve the maximal rate of channel gating observed in vivo [16,17].

Using the CFTR ATPase assay (Fig. 5), we next explored the question of whether (R domain) phosphorylation affects the kinetics of the ATP hydrolysis. This work failed to show an effect of either dephosphorylation (with PP2B) or with phosphorylation (using PKA) on the CFTR ATPase (Table II), in contrast to an early suggestion that phosphorylation might increase the affinity for MgATP [16,40]. Instead, these more recent tests (Fig. 5, Table II), together with our findings described above (Fig. $4 f g$ ) indicate that $\mathrm{R}$ domain phosphorylation in vitro has little or no effect on either nucleotide binding (single turnover) or net hydrolytic rate (many turnovers).

Previous electrophysiological work [44] has suggested that CFTR channel function is modulated when reduced glutathione (GSH) is present at the cytosolic surface, and a more recent report indicates that thismodulation may be evident at a macroscopic level as an inhibition of CFTR-mediated ATP hydrolysis [45]. Accordingly, the ATPase activity of purified CFTR was monitored (as above) in the presence of this putative modulator (Fig. 5). At a final concentration of $10 \mathrm{mM} \mathrm{GSH}$, the maximal velocity of CFTR ATPase was reduced about $40 \%\left(\mathrm{~V}_{\max }=34 \pm 5 \mathrm{nmol} / \mathrm{mg} / \mathrm{min}\right)$, without significant change in nucleotide affinity $\left(\mathrm{K}_{\mathrm{M}}\right.$ for MgATP of 0.11$)$. This reduction in maximal velocity was not observed in the presence of DTT (Fig. 5), suggesting GSH inhibits the ATPase activity of CFTR by a mechanism other than disulfide reduction.

\section{CFTR-dependent transport activity}

The work summarized above suggests that purified and reconstituted CFTR retains the features expected of nucleotide processing by an $\mathrm{ABC}$ transporter (Figs. 4 \& 5). A necessary complement to this work is an evaluation of whether the CFTR anion channel function is also evident. For this purpose, we monitored anion transport using a macroscopic in vitro assay based on the equilibrium exchange of proteoliposome-entrapped radioactive tracers [26,27]. Thus, we reconstituted purified CFTR as for the ATPase assay described above except that proteoliposomes were formed in the presence of both a CFTR channel substrate $\left({ }^{125} \mathrm{I}^{-}\right)$and an impermeant marker $\left({ }^{3} \mathrm{H}\right.$-glutamate). Efflux of proteoliposome-entrapped ${ }^{125} \mathrm{I}$, via CFTR as well as by non-specific routes, was initiated by resuspending proteoliposomes in buffer of exactly the same composition, but without addition of labeled tracers. In this way, ${ }^{125} \mathrm{I}^{-}$might leave proteoliposomes in net exchange for external non-radioactive $\mathrm{I}^{-}$, while ${ }^{3} \mathrm{H}$-glutamate, which is not expected to pass through the CFTR at a significant rate, would act as an internal control whose loss would account for tracer release due to proteoliposome breakage. After extended incubation (ca. $60 \mathrm{~min}$ ), proteoliposomes were isolated by filtration, and the net losses of entrapped ${ }^{125} \mathrm{I}$ and ${ }^{3} \mathrm{H}$-glutamate were noted. It should be emphasized that such an assay does not monitor individual channel openings and closings, and that, in principle, a positive 
finding may arise if a channel opens but then closes. With no added protein, both isotopes were lost to a comparable degree, corresponding to about 5-10\% of their initial values, and this was taken as the base line for comparison with losses noted when CFTR was present. In these latter cases, as the amount of CFTR used during reconstitution was increased, a clear bias favoring loss of ${ }^{125} \mathrm{I}$ developed, so that the isotope ratio $\left({ }^{125} \mathrm{I} /{ }^{3} \mathrm{H}\right)$ decreased from its reference value of 1.0 to near 0.3, reflecting CFTR-dependent efflux of ${ }^{125} \mathrm{I}$.

In experiments designed to probe the specificity of this response, we used an intermediate level of CFTR so as to obtain an isotope ratio $\left({ }^{125} \mathrm{I} /{ }^{3} \mathrm{H}\right)$ of about 0.5 , allowing us to survey conditions that might increase or decrease anion flux (Table III). We found that loss of ${ }^{125} \mathrm{I}$ was significantly reduced by chloride channel blockers known to act on CFTR (glibenclamide, DPC, DIDS), confirming that this behavior reflects a CFTR-like anion channel. We also found that GSH reduced CFTR-dependent transport of ${ }^{125}$ I, albeit to a lesser degree than did the chloride channel blockers (Table III). Finally, we asked if in vitro dephosphorylation (by PP2B) or phosphorylation (by PKA) affected anion flux. Indeed, while PKA had no effect on anion efflux, addition of PP2B appeared to eliminate a portion of the CFTR-dependent response (Table III), although this trend did not reach statistical significance.

\section{CFTR-dependent transport of ATP?}

There has been much debate concerning the possibility that ATP is transported by CFTR, driven either by ATP hydrolysis (as in other ABC transporters) or moving passively at low frequency via the embedded anion channel (for review see [46]). We were able to address this question directly with the in vitro transport assay by forming proteoliposomes in the presence of both ${ }^{3} \mathrm{H}$-glutamate and $\left[\alpha^{32} \mathrm{P}\right] \mathrm{ATP}$, and in the absence of halide anions to avoid competition with other channel substrates. As shown in Table III, the isotope ratio $\left({ }^{32} \mathrm{P} /{ }^{3} \mathrm{H}\right)$ ratio was similar for both control and CFTR-containing proteoliposomes, suggesting ATP is not a transport substrate for CFTR.

\section{DISCUSSION}

\section{Purification of functional CFTR}

A major obstacle to the mechanistic link between structure and function for $\mathrm{ABC}$ transporters has been the difficulty in purifying biochemical quantities of fully active protein. In particular, whether from natural sources or after over-expression in a heterologous system, CFTR usually proves refractory to solubilization with non-denaturing detergents commonly used in purifying membrane proteins (i.e., CHAPS, octylglucoside, dodecylmaltoside, etc. [33,35-38,47]). Accordingly, our first step was to establish an assay with which to gauge whether exposure to a test agent was compatible with long-term retention of the CFTR native state. For this purpose, we employed Az-ATP binding in the presence of a Vi-trap, and judged retention of the native structure by using UV light to cross-link Az-ATP still bound to CFTR after solubilization (Fig. 2 ). Based on these findings and on our other work with membrane proteins $[33,48,49]$ ), we established conditions for the solubilization of CFTR that include substrate stabilization (i.e., bound nucleotide), a combination of nonionic detergents (LPG + DHPC), addition of exogenous phospholipid and use of the chemical chaperone, glycerol. Following purification by Ni-agarose chromatography [32,33], we then used reconstituted material $[21,33]$ to document that the final product retains many of the attributes expected from earlier work. For example, use of a Vi-trap allowed us to show that purified CFTR displays nucleotide (Az-ATP) binding with an efficiency comparable to that of Pgp, a comparison we felt important to make directly, since the efficiency of UV cross-linking is low and may vary among laboratories. Indeed, for our work (Fig. 4), PgP had been purified using conditions optimized for its own recovery, and the preparation showed a basal ATPase activity and response to substrate consistent with what one expects for the fully functioning molecule (Table I). As a 
consequence, we conclude that nucleotide binding by CFTR is comparable to that shown by Pgp [36,38]. We also note that CFTR catalyzes a net hydrolysis of ATP (Fig. 5a and Table II) at rates comparable to several other ABC transporters, including Ste6p, ABCR, MRP1 and MRP2 [33,41-43]) and that this is sufficient to achieve the maximal rate of channel gating observed in vivo [16,17]. Finally, it is clear that purified CFTR mediates a halide-specific anion flux that can be inhibited by chloride channel blockers known to act on CFTR (Fig. 6 and Table III). Taken together, these results confirm that purification and reconstitution of functional CFTR can be achieved from an expression system capable of generating amounts of protein suited to extended biochemical and biophysical characterization.

\section{Role of $\mathbf{R}$ domain phosphorylation}

The cytoplasmic R domain, which distinguishes CFTR from other ABC transporters, contains 9 consensus sites $(\mathrm{R} / \mathrm{K}-\mathrm{R} / \mathrm{K}-\mathrm{X}-\mathrm{S} / \mathrm{T})$ for phosphorylation by protein kinases, the most important of which appears to be PKA [3,4]. Because deletion of the R domain activates the CFTR $\mathrm{Cl}^{-}$ channel $[4,50]$, it has been suggested that a dephosphorylated $\mathrm{R}$ domain may effectively occlude the conducting pore of CFTR, analogous to "ball and chain" inactivation of the Shaker $\mathrm{K}^{+}$channel in Drosophila [51]. R domain phosphorylation may therefore cause a conformational change within the molecule, alleviating a steric blockade and thereby facilitating nucleotide-dependent channel regulation. It has also been proposed that phosphorylation of the $\mathrm{R}$ domain alters the kinetics of nucleotide binding [52]. The experiments supporting such models of $\mathrm{R}$ domain function rely largely on the in vivo analysis of channel activity, and we did not directly address such issues. We note, however, that our work with purified material failed to show significant phosphorylation-dependent effects on nucleotide processing, measured by either the Vi-trap of Az-ATP (Fig. 4d) or by net ATP hydrolysis (Table II). We cannot exclude the possibilities that CFTR was damaged during purification, causing an abnormal response to R domain phosphorylation, or that CFTR remains minimally phosphorylated (activated) following purification or after in vitro phosphatase treatment. Alternatively, if fully functional CFTR is recovered by our techniques, the simplest conclusion is that nucleotide binding and hydrolysis are not directly coupled to CFTR phosphorylation. This idea would not be compatible with early reports that $\mathrm{R}$ domain phosphorylation alters the Michaelis constant for ATP hydrolysis [16,40,52]. The origin of this discrepancy is not understood, but may be related to procedural differences. In particular, we note that the earlier experiments employed one or more detergents (Triton, NaPFO, SDS) that disrupt nucleotide binding during solubilization (see Fig. 2). It is feasible, and perhaps not unexpected, that phosphorylation of reconstituted protein might facilitate partial renaturation of one or both NBDs. While not compatible with this early view, our observations remain consistent with the $\mathrm{R}$ domain occlusion model noted above. It must be recalled that our test for CFTR-mediated anion transport is based on an equilibrium condition reached after an extended incubation. Such a test cannot monitor individual gating events or the global probability of opening, but gives a record of whether a channel opens at least once. Accordingly, binding and hydrolysis of ATP may occur with similar kinetics for both unphosphorylated and phosphorylated forms of CFTR, but only for the latter species would such nucleotide processing also affect channel gating. We note that our work may also suggest an alternative model in which the link between $\mathrm{R}$ domain phosphorylation and nucleotide binding and hydrolysis is mediated, in vivo, by elements that remain uncharacterized. This latter model should remain a speculation until further work is completed.

\section{In vitro transport by CFTR}

Nucleotide processing reflects operation of the CFTR NBDs, while the CFTR chloride channel is assigned to the TMDs. To assess the functional status of CFTR-mediated anion transport, we exploited an in vitro assay based on the equilibrium exchange of proteoliposome-entrapped radioactive tracers (Fig. 6 and Table III). This assay, used earlier to study the bacterial chloride 
channel, EriC [26,27], verified recovery of CFTR channel function with appropriate responses to chloride channel blockers. The more general utility of this assay is also worth comment, since we were able to use it to exclude the possibility of ATP transport via CFTR (Table III). We anticipate that similar tests can be used to evaluate CFTR-mediated movements of other anions, some of which have been suggested as substrates (e.g., gluconate, pyruvate, formate, isothionate, bicarbonate and glutathione) [44,53,54]. We also note that the assay for anion transport uses the same experimental conditions as those used to monitor nucleotide processing. Thus, use of reconstituted CFTR provides a system with which one might study the functional linkage between these events (i.e., coupling). An equivalent survey using Pgp [22,36] identified a new class of agents, the "chemosensitizers," that stimulate ATPase activity without an effect on transport. A similar survey of CFTR might be useful in revealing novel modulators that affect coupling, either negatively or positively.

\section{ACKNOWLEDGMENTS}

We thank Dr. Christine Bear for providing baculovirus encoding recombinant CFTR and Dr. Suresh Ambudkar for the equivalent vector encoding Pgp.

This work was supported by Research Grants to CJK (KETCHU99FO) and PCM (MALONE00GO and MALONE03GO) from the Cystic Fibrosis Foundation, and to CJK (1 F32 DK09995-01) and PCM (DK48977) from the National Institutes of Health.

\section{Abbreviations}

ABC, ATP-binding cassette

$\mathrm{ABCR}$, human retinal transporter

Az-ATP, 8-azido- $\left[\alpha^{32} \mathrm{P}\right]$-adenosine-5'-triphosphate

$\beta$ gal, $\beta$-galactosidase

cAMP, adenosine- $3^{\prime}, 5^{\prime}$-cyclic monophosphate

CFTR, Cystic Fibrosis transmembrane conductance regulator

HisQMP $_{2}$, E. coli histidine permease

LPG, 1-palmitoyl-2-hydroxy-sn-glycero-3-[phospho-rac-(1-glycerol)]

DHPC, 1,2-diheptanoyl-sn-glycero-3-phosphocholine

DIDS, 4,4'-diisothiocyanostilbene-2,2'-disulfonic acid

DPC, diphenylamine carboxylate

$\mathrm{MalFGK}_{2}$, E. coli maltose transporter

MDR, multidrug resistance

MRP, multidrug resistance protein

NBD, nucleotide-binding domain

Pgp, P-glycoprotein

$\mathrm{Pi}$, inorganic phosphate

PKA, cAMP-dependent protein kinase

PP2B, protein phosphatase 2B or calcineurin

SDS-PAGE, sodium dodecyl sulfate-polyacrylamide gel electrophoresis

$\mathrm{Sf} 9$, Spodoptera frugiperda ovarian insect cells

Ste6p, S. cerevisiae pheromone transporter

TMD, transmembrane domain

$\mathrm{Vi}$, sodium orthovanadate.

\section{REFERENCES}

1. Riordan JR, Rommens JM, Kerem B, Alon N, Rozmahel R, Grzelczak Z, Zielenski J, Lok S, Plavisic N, Chou J, Drumm ML, Iannuzzi MC, Collins FS, Tsui LC. Identification of the cystic fibrosis gene: 
Cloning and characterization of complementary DNA. Science 1989;245:1066-72. [PubMed: 2475911]

2. Anderson M, Rich DP, Gregory RJ, Smith AE, Welsh MJ. Generation of cAMP-activated chloride currents by expression of CFTR. Science 1991;251:679-82. [PubMed: 1704151]

3. Li M, McCann JD, Liedke CM, Nairn AC, Greengard P, Welsh MJ. Cyclic AMP-dependent protein kinase opens chloride channels in normal but not cystic fibrosis airway epithelium. Nature 1988;331:358-60. [PubMed: 2448645]

4. Cheng SH, Rich DP, Marshall J, Gregory RJ, Welsh MJ, Smith AE. Phosphorylation of the R domain by cAMP-dependent protein kinase regulates the CFTR chloride channel. Cell 1991;66:1027-36. [PubMed: 1716180]

5. Anderson MP, Berger HA, Rich DP, Gregory RJ, Smith AE, Welsh MJ. Nucleoside triphosphates are required to open the CFTR chloride channel. Cell 1991;67:775-84. [PubMed: 1718606]

6. Anderson MP, Gregory RJ, Thompson S, Souza DW, Paul S, Mulligan RC, Smith AE, Welsh MJ. Demonstration that CFTR is a chloride channel by alteration of its anion selectivity. Science 1991;253:202-5. [PubMed: 1712984]

7. Tabcharani JA, Chang XB, Riordan JR, Hanrahan JW. The cystic fibrosis transmembrane conductance regulator chloride channel. Iodide block and permeation. Biophys. J 1992;62:1-4. [PubMed: 1376160]

8. Akabas MH, Kaufmann C, Cook TA, Archdeacon P. Amino acid residues lining the chloride channel of the cystic fibrosis conductance regulator. J. Biol. Chem 1994;269:14865-8. [PubMed: 7515047]

9. Cheung M, Akabas MH. Locating the anion-selectivity filter of the cystic fibrosis transmembrane conductance regulator (CFTR) chloride channel. J. Gen. Physiol 1997;109:289-99. [PubMed: 9089437]

10. Akabas MH. Channel-lining residues in the M3 membrane-spanning segment of the cystic fibrosis transmembrane conductance regulator. Biochemistry 1998;37:12233-40. [PubMed: 9724537]

11. Ketchum CJ, Yue H, Alessi KA, Devidas S, Guggino WB, Maloney PC. Intracellular cysteines of the Cystic Fibrosis Transmembrane Conductance Regulator (CFTR) modulate channel gating. Cell. Physiol. Biochem 2002;12:1-8. [PubMed: 11914543]

12. Ramjeesingh M, Li C, Garami E, Huan LJ, Galley K, Wang Y, Bear CE. Walker mutations reveal loose relationship between catalytic and channel-gating activities of purified CFTR (cystic fibrosis transmembrane conductance regulator). Biochemistry 1999;38:1463-68. [PubMed: 9931011]

13. Kartner N, Hanrahan JW, Jensen TJ, Naismith AL, Sun S, Ackerly CA, Reyes EF, Tsui LC, Rommens JM, Bear CE, Riordan JR. Expression of the cystic fibrosis gene in non-epithelial invertebrate cells produces a regulated anion conductance. Cell 1991;64:681-91. [PubMed: 1705179]

14. Szabo K, Szakacs G, Hegedus T, Sarkadi B. Nucleotide occlusion in the human cystic fibrosis transmembrane conductance regulator. J. Biol. Chem 1999;274:12209-12. [PubMed: 10212185]

15. Aleksandrov L, Mengos A, Chang X, Aleksandrov A, Riordan JR. Differential interactions of nucleotides at the two nucleotide binding domains of the Cystic Fibrosis Transmembrane Conductance Regulator. J. Biol. Chem 2001;276:12918-23. [PubMed: 11279083]

16. Li M, Ramjeesingh M, Wang W, Garami E, Hewryk M, Lee D, Rommens JM, Galley K, Bear CE. ATPase activity of the cystic fibrosis transmembrane conductance regulator. J. Biol. Chem 1996;271:28463-68. [PubMed: 8910473]

17. Senior AE, Gadsby DC. ATP hydrolysis cycles and mechanism in P-glycoprotein and CFTR. Semin. Cancer Biol 1997;8:143-50. [PubMed: 9441944]

18. Ramjeesingh M, Li C, Garami E, Huan L-J, Hewryk M, Wang Y, Galley K, Bear CE. A novel procedure for the efficient purification of the cystic fibrosis transmembrane conductance regulator (CFTR). Biochem. J 1997;327:17-21. [PubMed: 9355728]

19. Crawford I, Maloney PC, Zeitlin PL, Guggino WB, Hyde SC, Turley H, Gatter KC, Harris A, Higgins CF. Immunocytochemical localization of the cystic fibrosis gene product CFTR. Proc. Natl. Acad. Sci. U.S.A 1991;88:9262-6. [PubMed: 1718002]

20. Kaplan RS, Pederson PL. Determination of microgram quantities of protein in the presence of milligram levels of lipid with amido black 10B. Anal. Biochem 1985;150:97-104. [PubMed: 4083487]

21. Ambudkar SV, Larson TJ, Maloney PC. Reconstitution of sugar phosphate transport systems of Escherichia coli. J. Biol. Chem 1986;261:9083-6. [PubMed: 3522583] 
22. Ambudkar SV, Lelong IH, Zhang J, Cardarelli CO, Gottesman MM, Pastan I. Partial purification and reconstitution of the human multidrug-resistance pump: characterization of the drug-stimulatable ATP hydrolysis. Proc. Natl. Acad. Sci. USA 1992;89:8472-76. [PubMed: 1356264]

23. Fann MC, Maloney PC. Kinetic symmetry of UhpT, the sugar phosphate transporter of Escherichia coli. J. Biol. Chem 1998;273:33735-40. [PubMed: 9837961]

24. Fu D, Sarker RI, Abe K, Bolton E, Maloney PC. Structure/function relationships in OxIT, the oxalateformate transporter of Oxalobactor formigenes. J. Biol. Chem 2001;276:8753-60. [PubMed: 11113128]

25. Goodno CC. Myoson active-site trapping with vanadate ion. Methods Enzymol 1982;85:116-23. [PubMed: 6922391]

26. Maduke M, Pheasant DJ, Miller C. High-level expression, functional reconstitution, and quaternary structure of a prokaryotic ClC-type chloride channel. J. Gen. Physiol 1999;114:713-22. [PubMed: 10539975]

27. Mindell JA, Maduke M, Miller C, Grigorieff N. Projection structure of a ClC-type chloride channel at 6.5A resolution. Nature 2001;409:219-23. [PubMed: 11196649]

28. Cantley LC, Cantley LG, Josephson L. A characterization of vanadate interactions with (Na,K)ATPase. J. Biol. Chem 1978;253:7361-68. [PubMed: 212422]

29. Inesi G. Mechanism of calcium transport. Ann. Rev. Physiol 1985;47:573-601. [PubMed: 2581506]

30. Huang P, Liu Q, Scarborough GA. Lysophoshatidylglycerol: a novel effective detergent for solubilizing and purifying the cystic fibrosis transmembrane conductance regulator. Anal. Biochem 1998;259:89-97. [PubMed: 9606148]

31. Bear CE, Li C, Kartner N, Bridges RJ, Jensen TJ, Ramjeesingh M, Riordan JR. Purification and functional reconstitution of the cystic fibrosis transmembrane regulator (CFTR). Cell 1992;68:80918. [PubMed: 1371239]

32. Loo TW, Clarke DM. Rapid purification of human P-glycoprotein mutants expressed transiently in HEK 293 cells by nickel-chelate chromatography and characterization of their drug-stimulated ATPase activities. J. Biol. Chem 1995;270:21449-52. [PubMed: 7665554]

33. Ketchum CJ, Schmidt WK, Rajendrakumar GV, Michaelis S, Maloney PC. The yeast a-factor transporter, Ste6p, a member of the ABC Superfamily, couples ATP hydrolysis to pheromone export. J. Biol. Chem 2001;276:29007-11. [PubMed: 11389139]

34. Sauna SE, Ambudkar SV. Characterization of the catalytic cycle of ATP hydrolysis by human Pglycoprotein. The two ATP hydrolysis events in a single catalytic cycle are kinetically similar but affect different functional outcomes. J. Biol. Chem 2001;276:11653-61. [PubMed: 11154703]

35. Sarkadi B, Price EM, Boucher RC, Germann UA, Scarborough GA. Expression of the human multidrug resistance cDNA in insect cells generates a high activity drug-stimulated membrane ATPase. J. Biol. Chem 1992;267:4854-58. [PubMed: 1347044]

36. Urbatsch IL, Al-Shawi MK, Senior AE. Characterization of the ATPase activity of purified Chinese hamster P-glycoprotein. Biochemistry 1994;33:7069-76. [PubMed: 7911680]

37. Mao Q, Scarborough GA. Purification of functional human P-glycoprotein expressed in Saccharomyces cerevisiae. Biochim. Biophys. Acta 1997;1327:107-18. [PubMed: 9247172]

38. Urbatsch IL, Beaudet L, Carrier I, Gros P. Mutations in either nucleotide-binding site of Pglycoprotein $(\mathrm{Mdr} 3)$ prevent vanadate trapping of nucleotide at both sites. Biochemistry 1998;37:4592-602. [PubMed: 9521779]

39. Fischer H, Illek B, Machen TE. Regulation of CFTR by protein phosphatase 2B and protein kinase C. Eur. J. Physiol 1998;436:175-81.

40. Ko YH, Pederson PL. The first nucleotide binding fold of the cystic fibrosis conductance regulator can function as an active ATPase. J. Biol. Chem 1995;270:22093-96. [PubMed: 7545672]

41. Sun H, Molday RS, Nathans J. Retinal stimulates ATP hydrolysis by purified and reconstituted ABCR, the photoreceptor-specific ATP-binding cassette transporter responsible for Stargardt disease. J. Biol. Chem 1999;274:8269-81. [PubMed: 10075733]

42. Mao Q, Leslie EM, Deeley RG, Cole SPC. ATPase activity of purified and reconstituted multidrug resistance protein MRP1 from drug-selected H69AR cells. Biochim. Biophys. Acta 1999;1461:6982. [PubMed: 10556489] 
43. Hagmann W, Niles AT, Konig J, Frey M, Zentgraf H, Keppler D. Purification of the human apical conjugate export pump MRP2. Eur. J. Biochem 1999;265:281-9. [PubMed: 10491184]

44. Linsdell P, Hanrahan JW. Glutathione permeability of CFTR. Am. J. Physiol 1998;275:C323-6. [PubMed: 9688865]

45. Kogan I, Ramjeesingh M, Huan LJ, Wang Y, Bear CE. Perturbation of the pore of the cystic fibrosis transmembrane conductance regulator (CFTR) inhibits its ATPase activity. J. Biol. Chem 2001;276:11575-81. [PubMed: 11124965]

46. Schwiebert EM. ABC transporter-facilitated ATP conductive transport. Am. J. Physiol 1999;276:C18. [PubMed: 9886914]

47. Crawford IT, Maloney PC. Identification of cystic fibrosis transmembrane conductance regulator in renal endosomes. Methods Enzymol 1998;292:652-63. [PubMed: 9711589]

48. Bishop L, Agbayani R, Ambudkar SV, Maloney PC, Ames GF. Reconstitution of a bacterial periplasmic permease in proteoliposomes and demonstration of ATP hydrolysis concomitant with transport. Proc. Natl. Acad. Sci. USA 1989;86:6953-57. [PubMed: 2674940]

49. Fu D, Maloney PC. Evaluation of secondary structure of OxlT, the oxalate transporter of Oxalobacter formigenes, by circular dichroism spectroscopy. J. Biol. Chem 1997;1997:2129-35. [PubMed: 8999913]

50. Rich DP, Gregory RJ, Anderson MP, Manalavan P, Smith AE, Welsh MJ. Effect of deleting the R domain on CFTR-generated chloride channels. Science 1991;253:205-7. [PubMed: 1712985]

51. Zagotta WN, Hoshi T, Aldrich RW. Restoration of inactivation in mutants of Shaker potassium channels by a peptide derived from ShB. Science 1990;250:568-71. [PubMed: 2122520]

52. Li M, Ramjeesingh M, Reyes E, Jensen T, Chang X, Rommens JM, Bear CE. The cystic fibrosis mutation (delta F508) does not influence the chloride channel activity of CFTR. Nature Genet 1993;3:311-16. [PubMed: 7526932]

53. Smith JJ, Welsh MJ. cAMP stimulates bicarbonate secretion across normal, but not cystic fibrosis airway epithelia. J. Clin. Invest 1992;89:1148-53. [PubMed: 1313448]

54. Willumsen NJ, Boucher RC. Intracellular $\mathrm{pH}$ and its relationship to regulation of ion transport and cystic fibrosis human nasal epithelium. J. Physiol 1992;455:247-69. [PubMed: 1336551] 


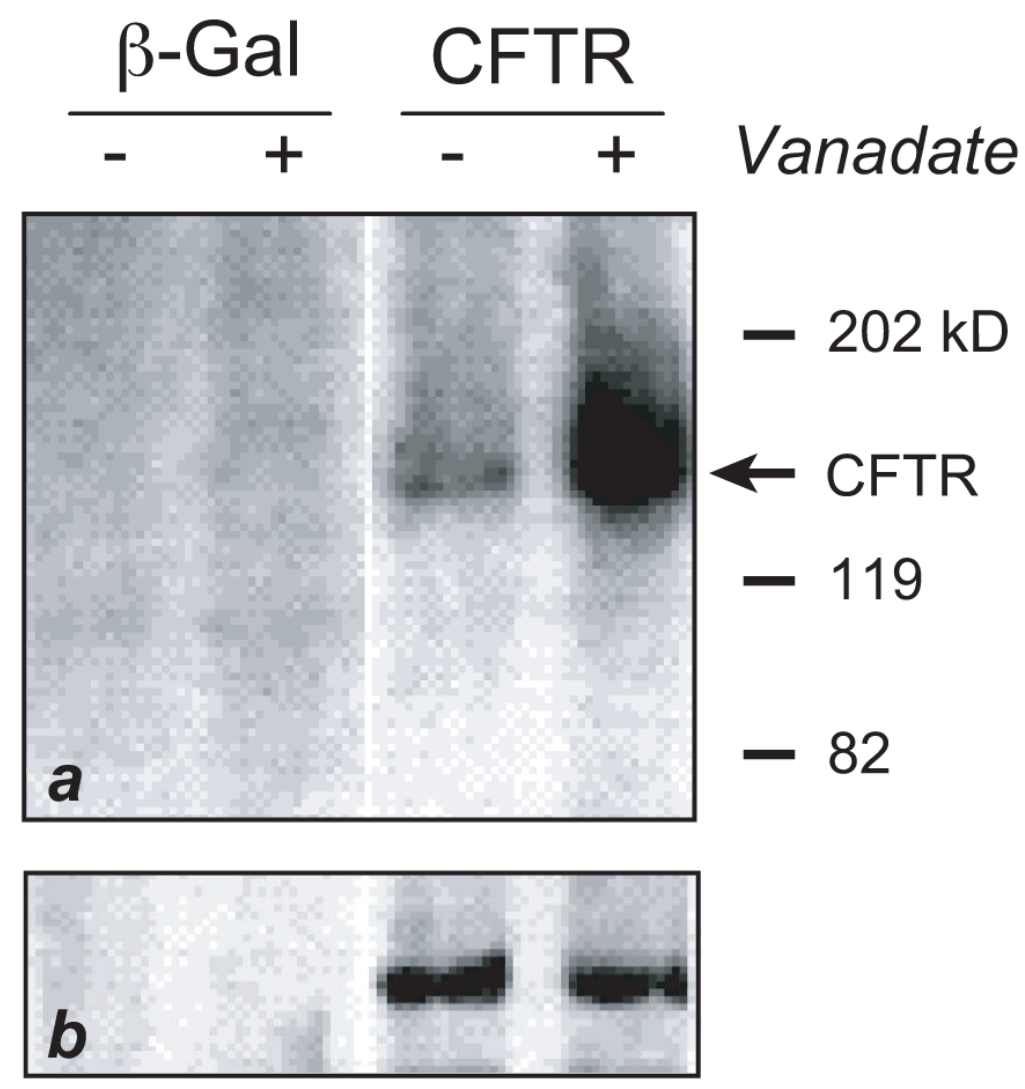

Figure 1. Vi-stimulated Az-ATP binding to CFTR in Sf9 membranes

Membranes prepared from Sf9 cells expressing either $\beta$-galactosidase $(\beta \mathrm{Gal})$ or CFTR were treated with 8 -azido- $\left[\alpha^{32} \mathrm{P}\right]$-ATP at a nominal concentration of $5 \mu \mathrm{M}$, in the presence or absence of $0.5 \mathrm{mM} \mathrm{Vi}$ as described in Methods, before exposure to UV light to cross-link the reactive probe to CFTR. The top panel (a) gives the autoradiograph, while the bottom panel (b) shows an immunoblot of the same gel probed with a polyclonal antibody against the $\mathrm{R}$ domain. 


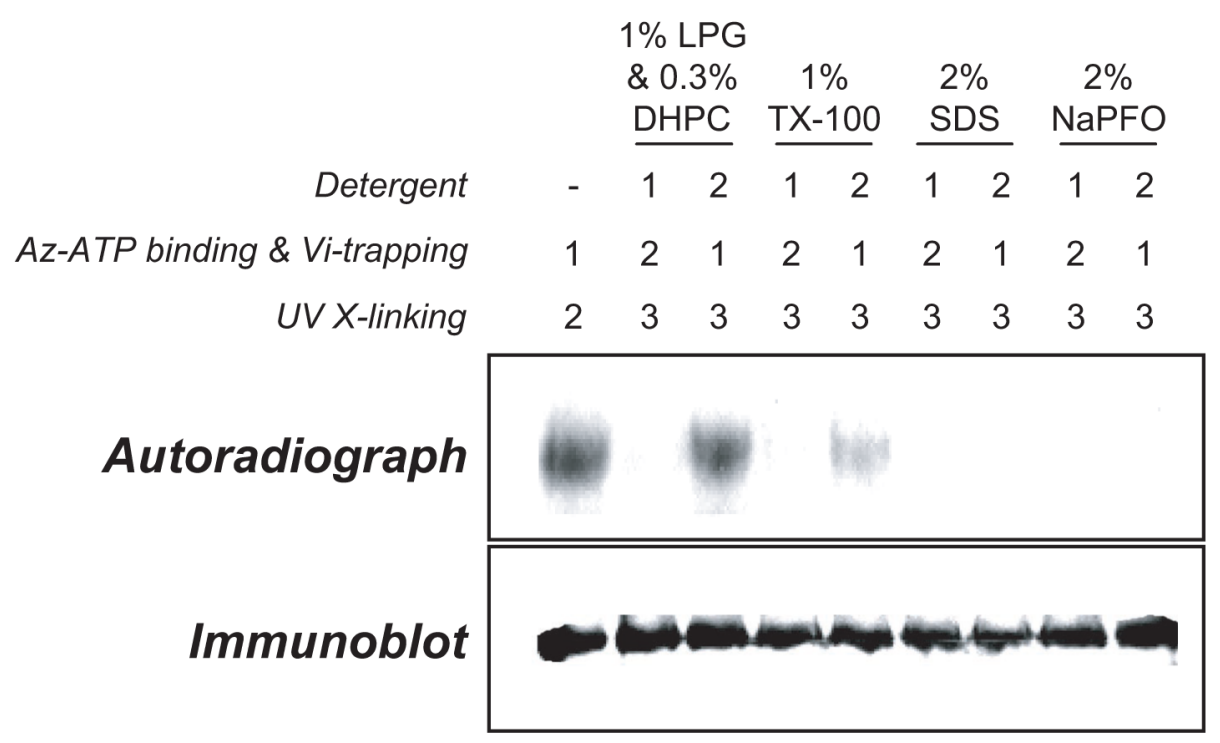

Figure 2. The effect of detergent solubilization on Az-ATP binding by CFTR

As noted, Sf9 membranes containing CFTR were exposed to the indicated detergents before (\#1) or after (\#2) exposure to Az-ATP in the presence of Vi. UV cross-linking was performed last, as indicated. Proteins were separated by SDS-PAGE and transferred to nitrocellulose. After recording signals using a Fuji Phosphoimager, CFTR was localized on the same nitrocellulose membrane by immunoblot using the $\mathrm{R}$ domain polyclonal antibody. 


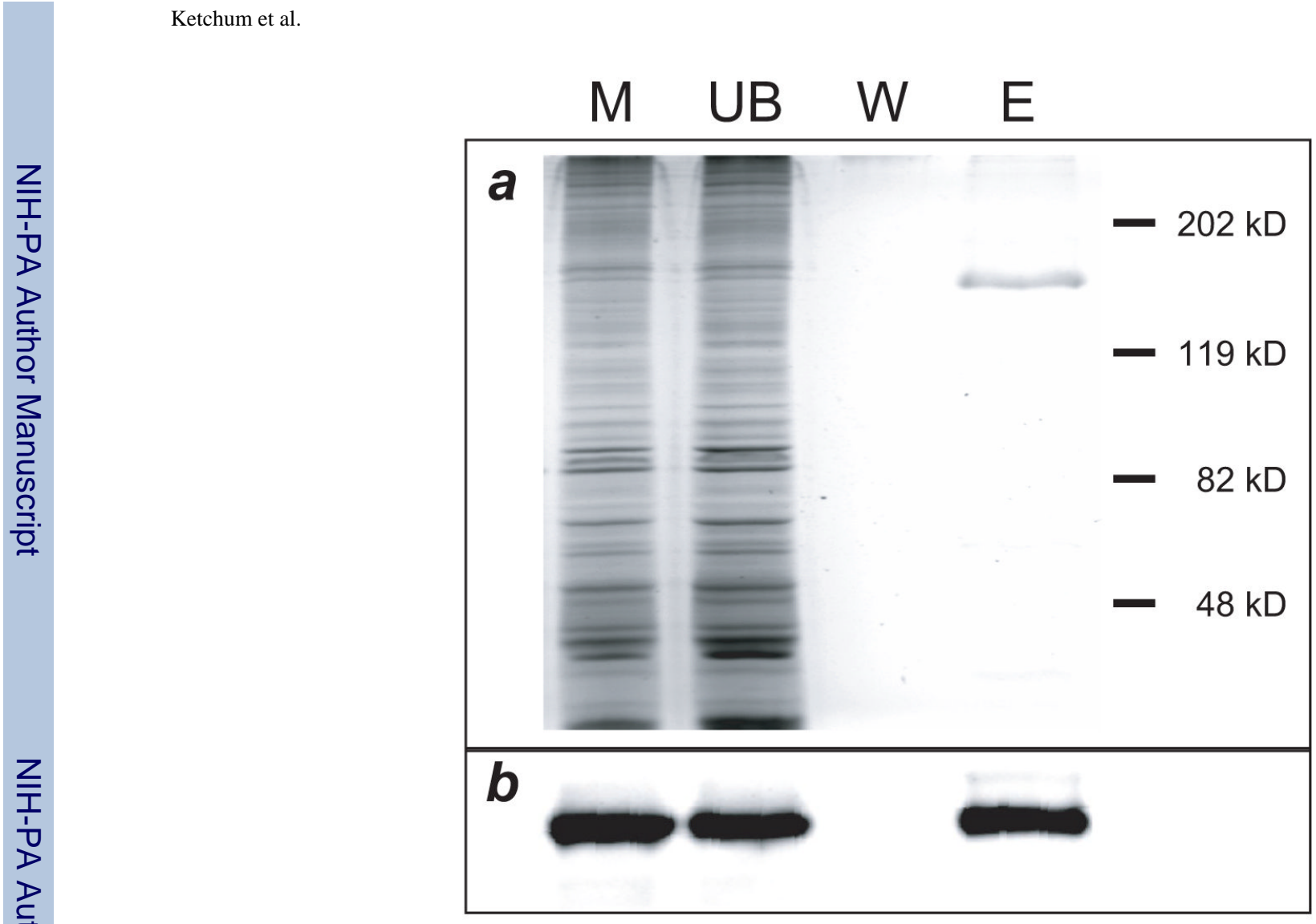

\section{Figure 3. Purification of CFTR}

Sf9 membranes (M) expressing CFTR were solubilized and mixed with Ni-affinity resin. The unbound (UB) fraction was collected, the resin washed (W), and purified protein eluted (E). For each preparation, a small aliquot of each fraction $(0.04 \%$ of $\mathrm{M}$ and UB, $0.4 \%$ of W, and $4 \%$ of E) was loaded onto duplicate gels for silver-staining $(\boldsymbol{a})$ and immunoblotting $(\boldsymbol{b})$. 

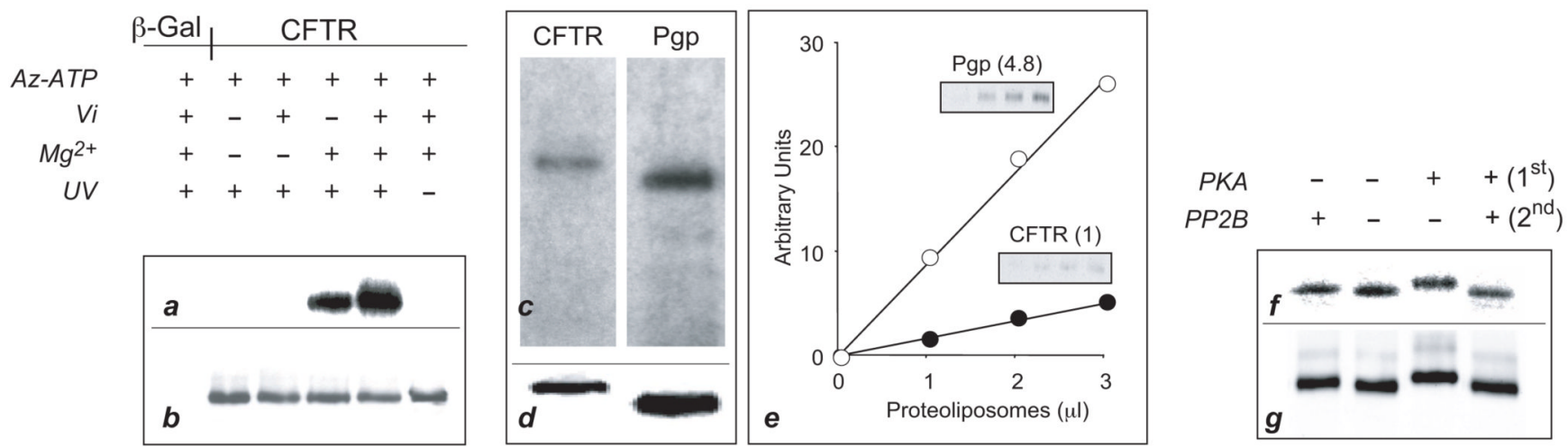

Figure 4. Vi trap of Az-ATP bound by purified and reconstituted CFTR

Sf9 membranes expressing CFTR, Pgp or $\beta$ Gal were solubilized, and purified protein (or the equivalent fraction for $\beta$ Gal-expressing cells) was reconstituted and subjected to Az-ATP binding and Vi-trapping. After SDS-PAGE and transfer to nitrocellulose, the nitrocellulose membrane was first exposed to a Fuji Phosphoimager screen $(\boldsymbol{a})$ and then immunoblotted $(\boldsymbol{b})$ using a monoclonal antibody directed against the $\mathrm{C}$-terminal $\mathrm{His}_{10}$ tags. The same techniques were used in a separate experiment using purified CFTR and $\operatorname{Pgp}(\boldsymbol{c}, \boldsymbol{d})$. In this case, the relative amounts of CFTR and Pgp in proteoliposomes were also determined by quantitative immunoblot analysis $(\boldsymbol{e})$, with band intensities quantified (arbitrary units) using Fuji Image Gauge V3.3 imaging software. Table II describes the characteristics of this preparation of Pgp. (f) In a third experiment, the effects of dephosphorylation by PP2B and phosphorylation by PKA were evaluated for purified CFTR, using methods described in Table IV. Az-ATP/Vitrapping was evaluated as described above; $(\boldsymbol{g})$ SDS-PAGE mobility was monitored with the monoclonal antibody reactive to the $\mathrm{C}$-terminal $\mathrm{His}_{10}$ tag. 

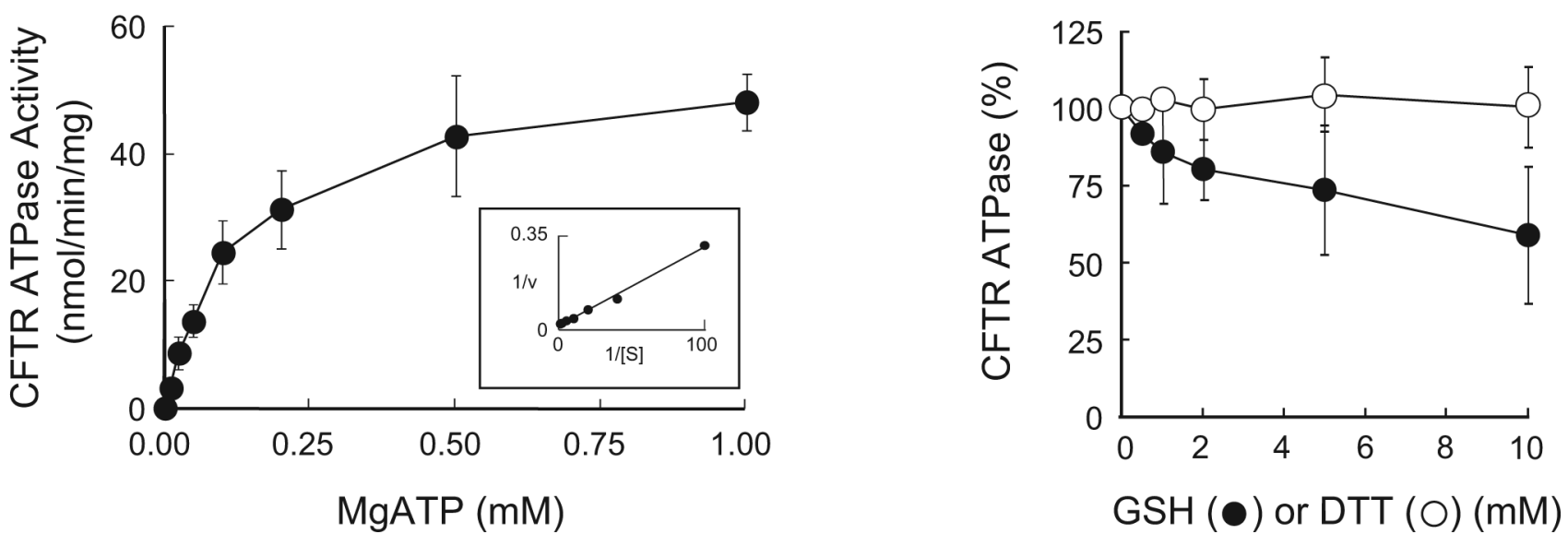

Fig. 5. ATPase activity of purified and reconstituted CFTR

(a) ATP hydrolysis was measured as a function of MgATP concentration; mean \pm SEM for 3-7 independent trials. $\mathrm{V}_{\mathrm{Max}}$ and $\mathrm{K}_{\mathrm{M}}$ were calculated from the best-fit linear regression of a Lineweaver-Burk plot (inset). (b) ATP hydrolysis was also monitored in the presence of increasing concentrations of GSH or DTT, as indicated. 


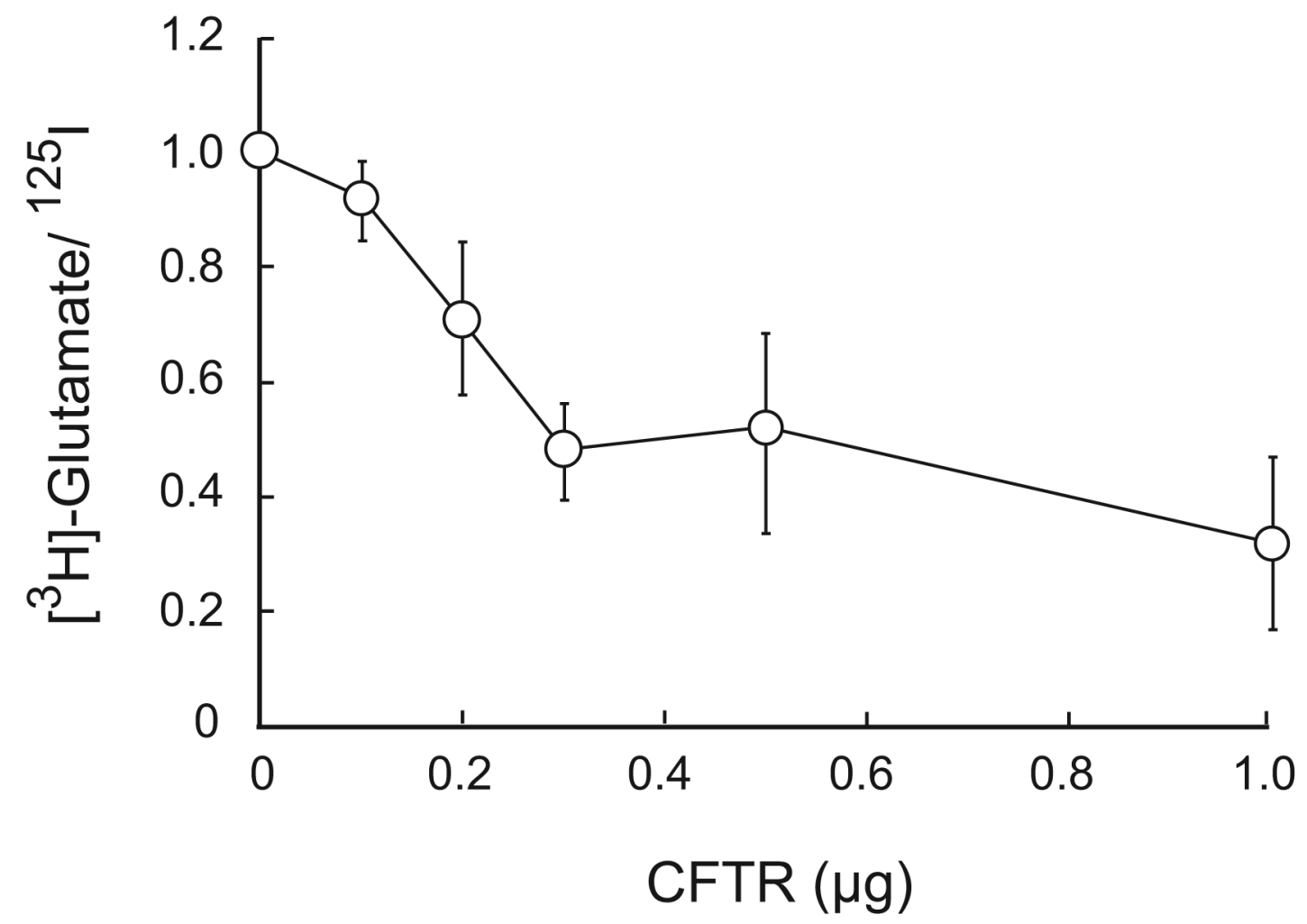

Fig. 6. Transport activity of purified and reconstituted CFTR

Transport was monitored by the equilibrium exchange of proteoliposome-entrapped ${ }^{125} \mathrm{I}$ and ${ }^{3} \mathrm{H}$-glutamate, using increasing amounts of purified CFTR during reconstitution; mean \pm SEM for 3-7 independent trials. 
Table I

ATPase of Purified Pgp Reconstituted in Proteoliposomes

\begin{tabular}{|c|c|c|}
\hline & $\mathrm{V}_{\mathrm{Max}}{ }^{a}(\mathrm{nmol} / \mathrm{min} / \mathrm{mg})$ & $K_{M}$ for $\operatorname{MgATP}^{b}(\mathrm{mM})$ \\
\hline $\begin{array}{l}\text { No Addition } \\
+10 \mu \mathrm{M} \text { Verapamil }\end{array}$ & $\begin{array}{c}400 \pm 25 \\
2400 \pm 125\end{array}$ & $\begin{array}{l}0.15 \\
0.14\end{array}$ \\
\hline
\end{tabular}


Table II

ATPase of Purified CFTR Reconstituted in Proteoliposomes

\begin{tabular}{lcc}
\hline & $\mathbf{V}_{\mathbf{M a x}} \boldsymbol{a}_{(\mathbf{n m o l} / \mathbf{m g} / \mathbf{m i n})}$ & $\mathbf{K}_{\mathbf{M}} \mathbf{f o r ~}^{\mathbf{M g A T P}} \boldsymbol{b}_{(\mathbf{m M})}$ \\
\hline $\mathrm{CFTR}+\mathrm{PP} 2 \mathrm{~B}^{c}$ & $53 \pm 6$ & 0.10 \\
$\mathrm{CFTR}$ & $58 \pm 5$ & 0.15 \\
$\mathrm{CFTR}^{c} \mathrm{PKA}^{d}$ & $54 \pm 4$ & 0.13 \\
$\mathrm{CFTR}+\mathrm{GSH}^{e}$ & $34 \pm 5$ & 0.11
\end{tabular}

${ }^{a}$ Maximal rate of ATP hydrolysis after correction for spontaneous Mg-catalyzed hydrolysis in mock controls (no protein). Hydrolysis was determined at $37^{\circ} \mathrm{C}$ as described in Methods. Data reflect mean values \pm SEM for 3 - 9 independent trials.

${ }^{b}$ Calculated from the best-fit linear regressions of Lineweaver-Burk plots.

${ }^{c}$ Proteoliposomes were resuspended in $100 \mu \mathrm{l}$ of assay buffer (see Methods) to which was added 1 unit PP2B (Sigma), 2 units calmodulin, and 0.2 mM $\mathrm{CaCl}$. Samples were placed at room temperature for $1 \mathrm{~h}$, and then centrifuged and washed with $5 \mathrm{ml}$ of assay buffer to remove components of the dephosphorylation mixture. ATP hydrolysis was then monitored as noted in Methods.

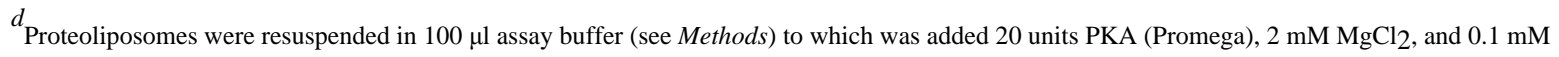
NaATP. Samples were placed at room temperature for $1 \mathrm{~h}$, and then centrifuged and washed with 5 ml of assay buffer to remove residual components of the phosphorylation reaction.

${ }^{e}$ Glutathione used at a final concentration of $10 \mathrm{mM}$. 
Table III

Transport Activity of Purified CFTR Reconstituted in Proteoliposomes

\begin{tabular}{|c|c|c|}
\hline & ${ }^{125} \mathbf{I} /{ }^{3}$ R Ratio $^{a}(\%)$ & {$\left[\alpha^{32} \mathrm{P}\right]-\mathrm{ATP} /{ }^{3} \mathrm{H}$-glutamate ${ }_{(\%)}^{b}$} \\
\hline $\begin{array}{l}\text { Control (no protein) } \\
\text { CFTR } \\
\text { CFTR + glibenclamide } \\
\text { CFTR + DPC } \\
\text { CFTR + DIDS } \\
\text { CFTR + glutathione } \\
\text { CFTR + PP2B } \\
\text { CFTR + PKA }\end{array}$ & $\begin{array}{c}100 \\
50 \pm 8 \\
95 \pm 11 \\
84 \pm 18 \\
90 \pm 17 \\
72 \pm 15 \\
66 \pm 9 \\
48 \pm 14\end{array}$ & $\begin{array}{c}108 \pm 10 \\
89 \pm 25 \\
\mathrm{ND}^{e} \\
\mathrm{ND} \\
\mathrm{ND} \\
\mathrm{ND} \\
\mathrm{ND} \\
\mathrm{ND}\end{array}$ \\
\hline
\end{tabular}

${ }^{a}$ As described in Methods; mean \pm standard error for 3 - 4 independent trials.

${ }^{b}$ Modified as follows: proteoliposomes were formed in a buffer containing $50 \mathrm{mM}$ Tris $\mathrm{HCl}(\mathrm{pH} 6.8), 50 \mathrm{mM} \mathrm{Kglutamate}(\mathrm{pH} 6.8) 2 \mathrm{mM} \mathrm{MgCl} 2,1 \mathrm{mM}$ $\mathrm{NaATP}$ and $1 \mathrm{mg} / \mathrm{ml}$ DTT, in the presence of $100 \mu \mathrm{Ci}\left[\alpha^{32} \mathrm{P}\right]$-ATP; proteoliposome-entrapped [ $\left.\alpha^{32} \mathrm{P}\right]$-ATP $/{ }^{3} \mathrm{H}$-glutamate counts were expressed as mean $\%$ of the mock control \pm standard error for 3 independent trials.

${ }^{c}$ Channel blockers were prepared as noted [11] and added to both sides of the membrane; final concentrations were $1 \mathrm{mM}$ glibenclamide, $1 \mathrm{mM}$ DPC, 5 mM DIDS, and $10 \mathrm{mM}$ glutathione.

$d$ $0.2 \mathrm{mM} \mathrm{CaCl}_{2}$ (i.e., dephosphorylation) or 20 units PKA (Promega), $2 \mathrm{mM} \mathrm{MgCl}_{2}$, and $0.1 \mathrm{mM} \mathrm{NaATP}$ (i.e., phosphorylation)

$e_{\text {Not Done }}$ 